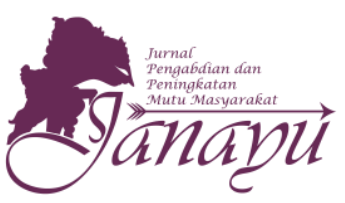

Website:

ejournal.umm.ac.id/index.php/janayu

Afiliasi:

${ }^{1}$ Program Studi Ekonomi

Pembangunan, ${ }^{2}$ Program Studi

Manajemen, Fakultas Ekonomi dan

Bisnis, Universitas Sultan Ageng

Tirtayasa, Indonesia

*Correspondence:

vadillamutia@untirta.ac.id

DOI: $\underline{10.22219 / j a n a y u . v 1 i 2.12385}$

Sitasi:

Zahara, V.M., Sanusi, F. \& Suci, S.C. (2020). Pengembangan Jejaring Bisnis Berbasis Produk Lokal Kota Cilegon. Jurnal Pengabdian dan Peningkatan Mutu Masyarakat, 1(2), 168- 177.

Proses Artikel

Diajukan:

4 Juni 2020

Direviu:

17 Juni 2020

Direvisi:

17 Juli 2020

Diterima:

23 Juli 2020

Diterbitkan:

29 Juli 2020

\author{
Alamat Kantor: \\ Jurusan Akuntansi Universitas \\ Muhammadiyah Malang \\ Gedung Kuliah Bersama 2 \\ Lantai 3. \\ Jalan Raya Tlogomas 246, \\ Malang, Jawa Timur, \\ Indonesia
}

P-ISSN: 2721-0421

E-ISSN: 2721-0340
Tipe Artikel: Paper Pengabdian

\section{Pengembangan Jejaring Bisnis Berbasis Produk Lokal Kota Cilegon}

\author{
Vadilla Mutia Zahara ${ }^{1 *}$, Fauji Sanusi², Stannia \\ Cahaya Suci ${ }^{1}$
}

\section{ABSTRACT}

Micro, Small and Medium Enterprises (MSMEs) are a potential sector for reducing unemployment, increasing income, which in turn has an impact on improving social welfare. One effort to develop MSMEs is to expand business networks, especially MSMEs with local products. The potential of local products such as Ceplis/Emping, palm sugar, Cilegon Batik, and various other typical products is interesting to the public both in Banten and outside Banten province. The technology that is developing at this time, especially the internet and social media, helps businesses to expand their market and business networks, but not a few businesses have not optimized digital technology to expand and develop their business networks. Through this workshop, MSME entrepreneurs are given training and assistance through the use of Google My Business and social media optimization, to help integrate both aspects of marketing both offline and online marketing.

KEYWORDS: Business Network; Digital Marketing ; Local Product; MSMEs.

\section{ABSTRAK}

Usaha Mikro Kecil dan Menengah (UMKM) merupakan sektor yang potensial dalam mengurangi angka pengangguran, meningkatkan pendapatan yang pada akhirnya berdampak pada peningkatan kesejahteraan masyarakat. Salah satu upaya dalam mengembangkan UMKM adalah dengan memperluas jejaring bisnis, khususnya UMKM produk lokal. Potensi produk lokal seperti emping, gula aren, batik cilegon, dan berbagai produk khas lainnya sangat diminati masyarakat baik di Banten maupun di luar provinsi Banten. Teknologi yang berkembang saat ini terutama internet dan media sosial membantu pelaku usaha untuk memperluas jaringan pasar dan usahanya, akan tetapi tidak sedikit pelaku usaha yang belum megoptimalkan teknologi digital untuk memperluas dan mengembangkan jejaring bisnisnya. Melalui pengabdian masyarakat ini, pelaku usaha UMKM diberikan pelatihan dan mendampingan melalui penggunaan Google Bisnisku dan pengoptimalan media sosial, untuk membantu mengitrasikan kedua aspek pemasaran baik secara offline maupun pemasaran secara online

KATA KUNCI: UMKM; Jejaring Bisnis; Produk Lokal; Pemasaran Digital 


\section{PENDAHULUAN}

Salah satu persoalan yang terjadi di Kota Cilegon adalah tingkat kesejahteraan masyarakat. Berdasarkan data Badan Pusat Statistik pertumbuhan ekonomi kota Cilegon tahun 2018 adalah 5,83\% angka ini lebih besar dari pada pertumbuhan ekonomi Provinsi Banten yaitu $5,81 \%$. Pertumbuhan ekonomi yang tinggi ini, tidak menunjukan kesejahteraan yang merata disetiap lapisan masyarakat. Hal ini tercermin dari angka indeks Theil sebesar 9.95, yang artinya Cilegon merupakan daerah maju tapi lamban tumbuh, dan merupakan salah satu daerah di Provinsi Banten yang memiliki tingkat ketimpangan tinggi.

Penyebab ketimpangan di kota Cilegon terjadi karena masuknya perusahaan-perusahaan asing (Dhyatmika, 2013), selain itu pembangunan daerah tidak diimbangi dengan peningkatan kualitas sumber daya manusia, sehingga para perusahaan memperkerjakan para pekerjanya dari luar Kota Cilegon Hal ini didukung oleh data dari (BPS, 2019) yang mencatat jumlah pengangguran di Cilegon masih relatif tinggi, yakni 9,33\%. Penurunan tingkat pengangguran merupakan salah satu isu strategis yang tertera pada Renstra RPJMD Kota Cilegon 2016-2021yang menargetkan angka pengangguran turun hingga 7,01\%.

Upaya mengurangi angka pengangguran dapat dilakukan melalui pemberdayaan masyarakat di sektor Usaha Mikro Kecil dan Menengah (UMKM). UMKM memiliki potensi meningkatkan pendapatan serta membantu penyerapan tenaga kerja (Supriyanto, 2012). Akan tetapi, jumlah UMKM di kota Cilegon relatif sedikit jika dibandingkan dengan kabupaten kota lain di provinsi Banten. Angka ini perlu ditingkatkan, mengingat kota Cilegon yang merupakan daerah strategis dan potensial untuk mengembangkan bisnis khusunya UMKM berbasis produk lokal. Agar hal tersebut dapat teratasi, perlunya keterbukaan lapangan pekerjaan baru, dan peningkatan sumberdaya, terutama sumberdaya yang berbasis lokal (Endaryono \& Djuhartono, 2018). Pengembangan masyarakat khususnya para pelaku usaha mikro kecil dan menengah (UMKM) dapat menciptakan pelaku-pelaku usaha baru dalam mengembangankan produk lokal kota Cilegon dan selanjutnya dapat membuka lapangan kerja baru bagi masyarakat yang nantinya akan berdampak pada peningkatan kesejahteraan masyarakat.

\begin{tabular}{lrrrr}
\hline Kabupaten/ Kota & $\begin{array}{l}\text { Usaha } \\
\text { Mikro }\end{array}$ & \multicolumn{1}{c}{$\begin{array}{c}\text { Usaha } \\
\text { Kecil }\end{array}$} & $\begin{array}{c}\text { Usaha } \\
\text { Menengah }\end{array}$ & $\begin{array}{c}\text { Jumlah } \\
\text { UMKM }\end{array}$ \\
\hline Kabupaten Lebak & 49.498 & 825 & 15 & 50.338 \\
Kabupaten & 41.155 & 0 & 0 & 41.155 \\
$\begin{array}{l}\text { Tangerang } \\
\text { Kabupaten Serang }\end{array}$ & 22.667 & 3.958 & 284 & 26.909 \\
Kota Tangerang & 11.079 & 633 & 34 & 11.746 \\
Kota Cilegon & 6.446 & 100 & 0 & 6546 \\
Kota Serang & 6.495 & 3.595 & 222 & 10.321 \\
Kota Tangerang & 7.074 & 2.488 & 0 & 9.582 \\
$\begin{array}{l}\text { Selatan } \\
\text { Kabupaten }\end{array}$ & 900 & 100 & 2 & 1.002 \\
Pandeglang & & & & \\
\hline
\end{tabular}

Tabel 1. Jumlah UMKM di Provinsi Banten Tahun 2018 
Zahara, Sanusi \& Suci,, Pengembangan Jejaring Bisnis ...

Tabel 2.

Jumlah Mitra

Binaan Aktif

Berdasarkan

Kelurahan di

Kota Cilegon

2015

\begin{tabular}{lrrrr}
\hline Kelurahan & Perintisan & Penguatan & Pengembangan & Jumlah \\
\hline Cibeber & 424 & 395 & 103 & 922 \\
Cilegon & 284 & 522 & 116 & 922 \\
Citangkil & 620 & 820 & 310 & 1750 \\
Ciwandan & 219 & 487 & 151 & 857 \\
Jombang & 460 & 1135 & 225 & 1820 \\
Purwakarta & 173 & 628 & 77 & 878 \\
Grogol & 202 & 464 & 35 & 701 \\
Pulomerak & 99 & 68 & 64 & 231 \\
\hline
\end{tabular}

Permasalahan yang terjadi pada pelaku usaha diantaranya kurangnya inovasi, akses untuk pemasaran serta legalitas atau izin usaha para pelaku bisnis (Ariani \& Utomo, 2017). Potensi untuk mengembangkan produk lokal Kota Cilegon sangat menjanjikan, banyaknya produk lokal yang mulai dikembangkan diantaranya dari aspek Kuliner, Emping Melinjo, Ceplis dengan berbagai rasa, sate bandeng, kue engkak, kue gipang, bakso ikan lele, kerupuk dapros, sambal buroq dan rabeg, dan dari berbagai aspek lain seperti pariwisata, cenderamata, serta kesenian khas cilegon. Kurang siapnya UMKM dalam menghadapi tantangan globalisasi revolusi industri, perlu dorongan serta pendampingan secara intensif agar terciptanya iklim usaha yang baik. Meskipun jauh dari kata ideal, tapi peluang menciptakan bisnis baru di masyarakat sangat tinggi, keinginan masyarakat untuk berwirausaha, dan keterampilan serta didukung oleh indeks daya beli masyarakat Cilegon yang tinggi, sebesar 77,93 (BPS, Cilegon Dalam Angka, 2018).

Dalam Restra Dinas Koperasi Kota Cilegon 2016-2021 terdapat beberapa tahap yang ditetapkan dalam RPJP tahun 2005-2025 salah satunya adalah menjadikan kota Cilegon kota yang Mandiri dan Sejahtera, fokus prioritas pembangunan diarahkan pada peningkatan kemitraan UMKM melalui link and match dari hulu ke hilir, menumbuhkan industri padat karya, usaha berbasis teknologi, penguatan pemberdayaan ekonomi lokal dan penerapan konsep one village one product dalam pengembangan UMKM. (Disperindag, 2018)

Berikut merupakan data mitra binaan Dinas Perdagangan, Industri dan Koperasi (DISPERINDAGKOP) dan Pusat Inkubator Wirausaha dan UMKM (PIWKU) yang aktif dari berbagai aspek usaha baik usaha perintisan, penguatan sampai aspek usaha yang sudah dikembangkan yang berkerjasama dengan dinas perindustrian, perdagangan, koperasi serta mitra terkait berdasarkan kelurahan di Kota Cilegon sampai tahun 2015.

Keterbatasan waktu dan biaya pemasaran merupakan kendala utama bagi pelaku usaha untuk mengenalkan usaha dan memasarkan produknya di pasaran (Ramdansyah \& Taufik, 2017). Pada umumnya di kota cilegon produk lokal banyak dipasarkan di pusat oleh-oleh, dan beberapa gerai cendramata, yang biasa dibeli oleh masyarakat ataupun para wisatawan yang berkunjung ke kota Cilegon (Aliudin dan Dian Anggraeni, 2012). Dibutuhkan cara agar produk lokal juga dapat dipasarkan ke luar provinsi Banten, maupun ke mancanegara. Salah satunya adalah pemanfaatan digital marketing melalui, mesin pencari (google) ataupun media sosial(Chang Shia et al., 2015).

Terkadang konsumen lupa dengan nama produk yang akan dicari atau lupa dengan tempat/ gerai pemasaran ataupun konsumen ingin mengetahui ulasan mengenai suatu produk, maka pelaku usaha UMKM perlu mempromosikan produknya pada mesin pencari maupun media sosial, dengan berkembangnya jejaring bisnis UMKM terutama produk lokal, maka akan meningkatkan pendapatan masyarakat dan pendapatan inilah yang menjadi indikator

\section{Janayu} 1.2 
penting dalam meningkatkan berbagai aspek lain seperti pendidikan, kesehatan, sosial budaya, mutu layanan dan lain sebagainya.

Mengacu pada analisis situasi tersebut, permasalahan yang dihadapi mitra Dinas Perdagangan, Industri dan Koperasi (DISPERINDAGKOP) dan Pusat Inkubator Wirausaha dan UMKM (PIWKU) antara lain: (1) Terbatasnya jejaring bisnis berbasis produk lokal di Kota Cilegon (2) Rendahnya pengunjung pada gerai/ toko fisik/ offline para pelaku usaha (3) Produk usaha terutama berbasis lokal belum dikenal luas oleh masyarakat.

\section{METODE}

Berdasarkan pada analisis situasi dan permasalahan yang telah dibahas, maka upaya untuk menyelesaikan permasalahan yang dihadapi oleh mitra dan pelaku usaha dilakukan dengan berbagai pendekatan dalam bentuk pelatihan, diskusi dan pendampingan kepada mitra.

Melalui beberapa metode pendekatan pelatihan dan pendampingan yang disesuikan dengan target dan tujuan kegiatan, maka tahapan yang dilakukan adalah sebagai berikut:

\begin{tabular}{|c|c|c|c|}
\hline No. & Tujuan Kegiatan Program & Metode & $\begin{array}{l}\text { Partisipasi } \\
\text { Mitra }\end{array}$ \\
\hline 1 & $\begin{array}{l}\text { Pemahaman jejaring bisnis } \\
\text { antara UMKM dan Pemerintah } \\
\text { (DISPERINDAGKOP dan } \\
\text { PIWKU), serta peningkatan } \\
\text { keterampilan dalam penggunaan } \\
\text { internet dalam pemasaran secara } \\
\text { online }\end{array}$ & $\begin{array}{l}\text { Community development, } \\
\text { Persuasif dan } \\
\text { Edukatif } \\
\text { (penyampaian materi } \\
\text { tentang pentingnya } \\
\text { jejaring bisnis) }\end{array}$ & $\begin{array}{l}\text { Mitra menyimak } \\
\text { dan terlibat aktif } \\
\text { dalam } \\
\text { menyampaikan } \\
\text { pendapat dan } \\
\text { memberikan } \\
\text { informasi serta } \\
\text { situasi dan } \\
\text { kondisi yang } \\
\text { terjadi } \\
\text { dilapangan }\end{array}$ \\
\hline 2 & $\begin{array}{l}\text { Pemahaman penggunaan akun } \\
\text { Google Bisnisku untuk } \\
\text { pemasaran }\end{array}$ & $\begin{array}{l}\text { Community development, } \\
\text { Persuasif dan } \\
\text { Edukatif (Sosialisasi, } \\
\text { penyampaian materi } \\
\text { dan diskusi mengenai } \\
\text { penggunaan akun } \\
\text { Google binsisku) }\end{array}$ & $\begin{array}{l}\text { Mitra menyimak } \\
\text { dan terlibat aktif } \\
\text { dalam } \\
\text { menyampaikan } \\
\text { pendapat dan } \\
\text { mengemukakan } \\
\text { kendala dalam } \\
\text { membentuk } \\
\text { jejaring bisnis } \\
\text { pemasaran online }\end{array}$ \\
\hline 3 & $\begin{array}{l}\text { Pembuatan } \\
\text { Bisnisku }\end{array}$ & $\begin{array}{l}\text { Partisipatif dan } \\
\text { evaluasi (Tutorial } \\
\text { membuat dan } \\
\text { menggunakan akun } \\
\text { Google Bisnisku. } \\
\text { Evaluasi dan diskusi) }\end{array}$ & $\begin{array}{l}\text { Mitra aktif } \\
\text { mengikuti } \\
\text { tutorial yang } \\
\text { dijelaskan } \\
\text { pemateri dengan } \\
\text { menggunakan } \\
\text { gadget yang } \\
\text { dimiliki seperti } \\
\text { smartphone dan } \\
\text { laptop }\end{array}$ \\
\hline
\end{tabular}

Tabel 3.

Metode

Pendekatan

Pelatihan dan

Pendampingan 
Pelaksanaan pengabdian kepada masyarakat ini menggunakan metode pendekatan sebagai berikut:

1. Community Development : Pendekatan yang berorientasi kepada upaya-upaya pengembangan pemberdayaan para pelaku usaha UMKM berbasis produk lokal yang berada disetiap kelurahan-kelurahan di Kota Cilegon. Pelaku usaha tersebut selama ini dibina oleh Dinas Perindustrian, Perdagangan dan Koperasi (DISPERINDAGKOP) serta merupakan anggota tenant Pusat Inkubator Wirausaha dan Klinik UMKM (PIWKU). Dari banyaknya pelaku usaha di Kota Cilegon, dilakukan survei dan dipilih UMKM yang berbasis produksi lokal, baik kuliner, kerajinan tangan, maupun disektor jasa.

2. Persuasif : Dilakukan pendekatan berupa seruan dan ajakan agar pelaku usaha termotivasi untuk berusaha mengembangkan jejaring bisnisnya baik secara offline maupun online. Dalam metode ini dilakukan pendekatan berupa pelatihan dan pendampingan bagaimana mengembangkan jejaring bisnis dengan mengintegrasikan bisnis offline dan online media sosial ataupun market place dengan menggunakan google bisnisku (Google Mybusiness).

3. Edukatif : Pendekatan yang dilakukan menggandung unsur pendidikan bagi para peserta dengan harapan peserta mendapatan wawasan, ide, gagasan dan inovasi untuk usaha yang mereka jalankan.

4. Partisipatif : Peserta melakukan praktek langsung dibantu oleh narasumber dan panitia dari gapura digital untuk dapat mengakses, dan menggunakan google bisnisku.

5. Evaluasi: Pendekatan ini dilakukan dengan berdiskusi dari materi yang telah mereka peroleh serta mendiskusikan solusi atas permasalahan yang dihadapi mitra pelaku usaha UMKM.

\section{HASIL DAN PEMBAHASAN}

Hasil Kegiatan pelatihan bertemakan jejaring bisnis yang berfokus pada penggunaan aplikasi Google Bisnisku, yang dilakukan melalui tahap-tahap berikut:

\section{Persiapan Kegiatan, meliputi :}

Survei Peserta, yaitu para pelaku UMKM yang berbasis lokal, pada tahap ini dilakukan survei mengenai media pemasaran yang digunakan oleh para pelaku UMKM sebelum adanya pelatihan, dan hasil surveinya adalah sebagai berikut:

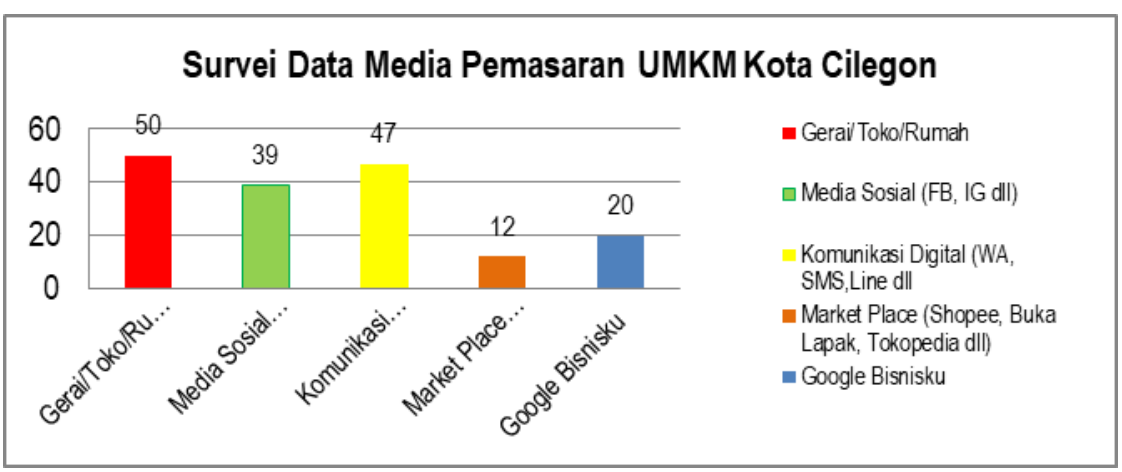


Kegiatan ini, diikuti oleh 50 peserta dari berbagai UMKM berbasis lokal yang tersebar di beberapa kelurahan di kota Cilegon. Hasil dari survei tersebut adalah, semua UMKM memasarkan produknya melalui gerai/ toko maupun rumah masing-masing, dibantu dengan komunikasi melalui digital seperti aplikasi whatsapp dan SMS. Hanya 39 pelaku usaha saja yang memasarkan melalui media sosial, 12 pelaku usaha memasarkan melalui market place dan hanya 20 pelaku usaha saja yang sudah mulai mengaplikasikan google bisnisku. Berdasarkan data tersebut, maka penting untuk pelaku usaha mengaplikasikan google bisnisku, agar terbentuk jejaring bisnis yang terintegrasi antara offline maupun online (Paul M. Muchinsky, 2012).

\section{Kegiatan seminar meliputi :}

a. Pembukaan yang diisi dengan sambutan Ketua Pelaksana, Dekan Fakultas Ekonomi dan Bisnis Universitas Sultan Ageng Tirtayasa dan Perwakilan Walikota Cilegon, ASDA II dan Ketua DPRD Kota Cilegon serta perkenalan dengan peserta yang merupakan pelaku usaha (UMKM) di berbagai bidang yang tergabung dalam PIWKU yang menjadi sasaran target kegiatan. Setelah itu, Penandatanganan Nota Kesepahaman antara FEB dengan Mitra Pusat Inkubator Wirausaha dan UMKM (PIWKU) Kota Cilegon
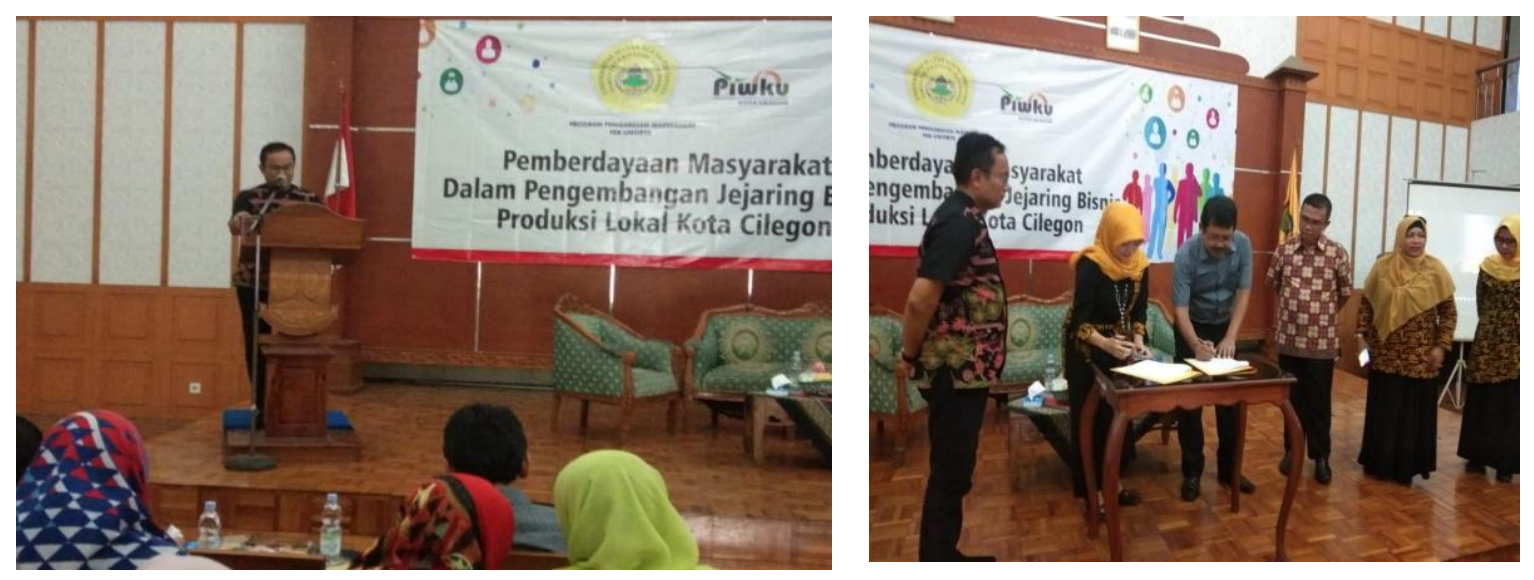

Gambar 1.

Sambutan ASDA II Kota Cilegon mewakili Walikota dan Prosesi

Penandatangana n Nota Kesepahaman

b. Pemaparan materi yang disampaikan oleh narasumber dari Gapura Digital mengenai penggunaan aplikasi Google Bisnisku dan cara penggunaanya. Serta Tips dan Trik membangun jejaring Bisnis melalui online sebagai media pemasaran.

Janayu 1.2

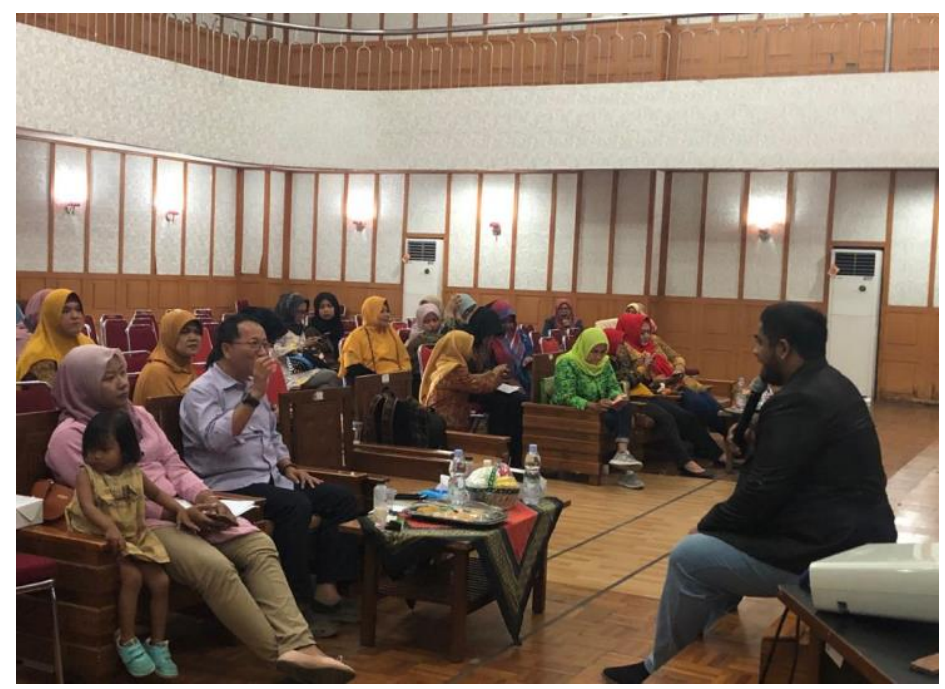

Gambar 2.

Pemaparan Materi Google Bisnisku oleh Gapura Digital 
c. Sesi diskusi/ tanya jawab dengan peserta Pemberdayaan masyarakat dalam membangun jejaring bisnis produksi lokal Kota Cilegon

d. Penutupan

Foto bersama dengan peserta pembinaan (pelaku UMKM di Kota Cilegon).

Gambar 3.

Foto bersama dengan

perwakilan mitra UMKM

Gambar 4.

Pembagian

Sertifikat pada para Peserta

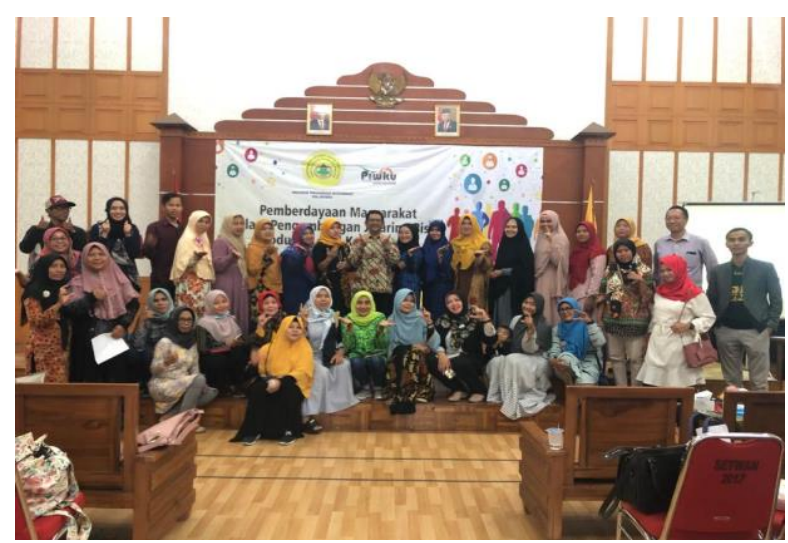

e. Penyerahan sertifikat kepada peserta.

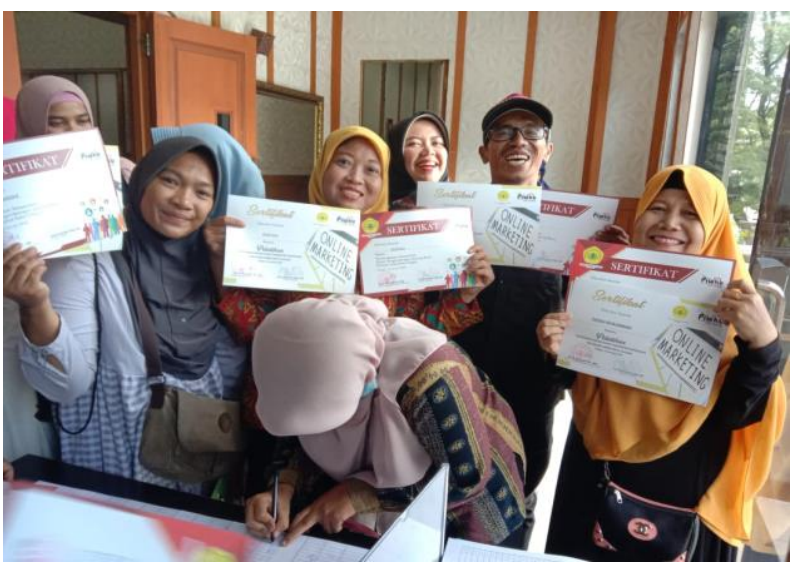

\section{Evaluasi Hasil}

Keberhasilan pelaksanaan program pengabdian masyarakat ini dilihat dari dua tolok ukur sebagai berikut:

a. Respon positif dari peserta pelatihan

Tanggapan dan umpan balik peserta pelatihan diukur melalui pengamatan langsung selama pelatihan. Hal tersebut dilakukan dengan cara memberikan kesempatan secara langsung kepada peserta untuk bertanya, menyampaikan pendapat dan langsung mengaplikasikan program google bisnisku, ditunjukan dari hasil survei pada grafik berikut yang menunjukan hasil yang positif, baik keseusian materi, penyampaian dan pemahaman peserta terhadap pelatihan yang diberikan, selain itu repon positif juga ditunjukan oleh keinginan peserta yang mengikuti pelatihan lebih lanjut. 


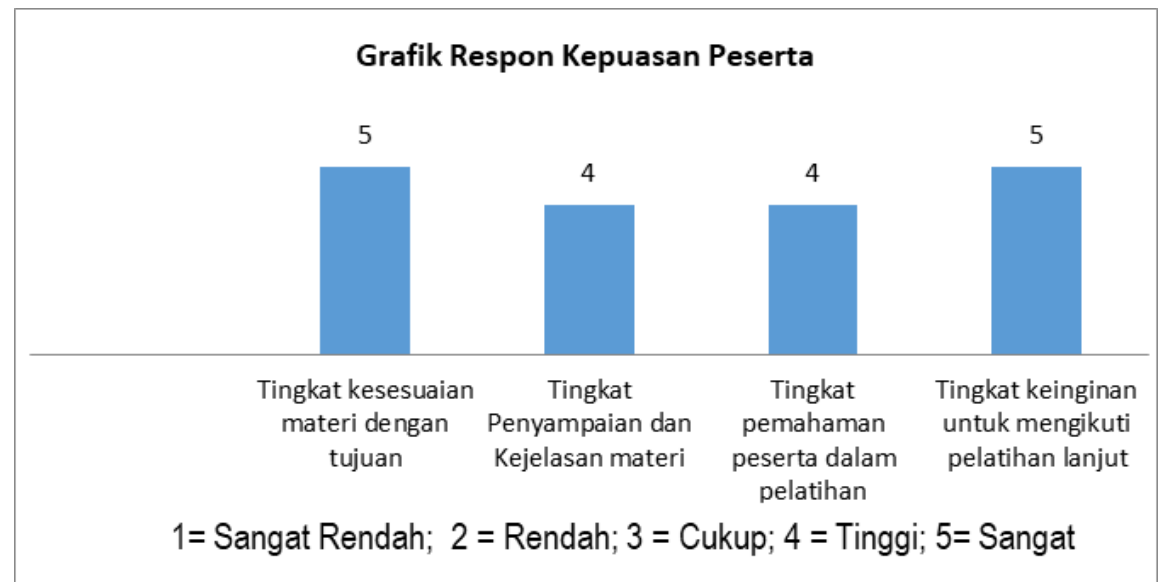

Grafik 2.

Respon

Kepuasan

Peserta

b. Meningkatnya keterampilan peserta setelah mendapat pelatihan

Outcome dari kegiatan pelatihan pengembangan jejaring bisnis ini adalah meningkatnya kemampuan dan keterampilan peserta pembinaan dalam membangun dan mengembangkan jejaring bisnis UMKM. Pasca pelatihan pengembangan jejaring bisnis lokal ini, para peserta mengaplikasikan hasil pelatihannya dengan membuat dan mengembangkan akun google bisnisku dan berbagai platform media pemasaran online lain, seperti instagram, facebook, whatsapp dan lain-lain, sehingga dapat mendorong pengembangan pemasaran yang pada akhirnya akan meningkatkan penjualan.
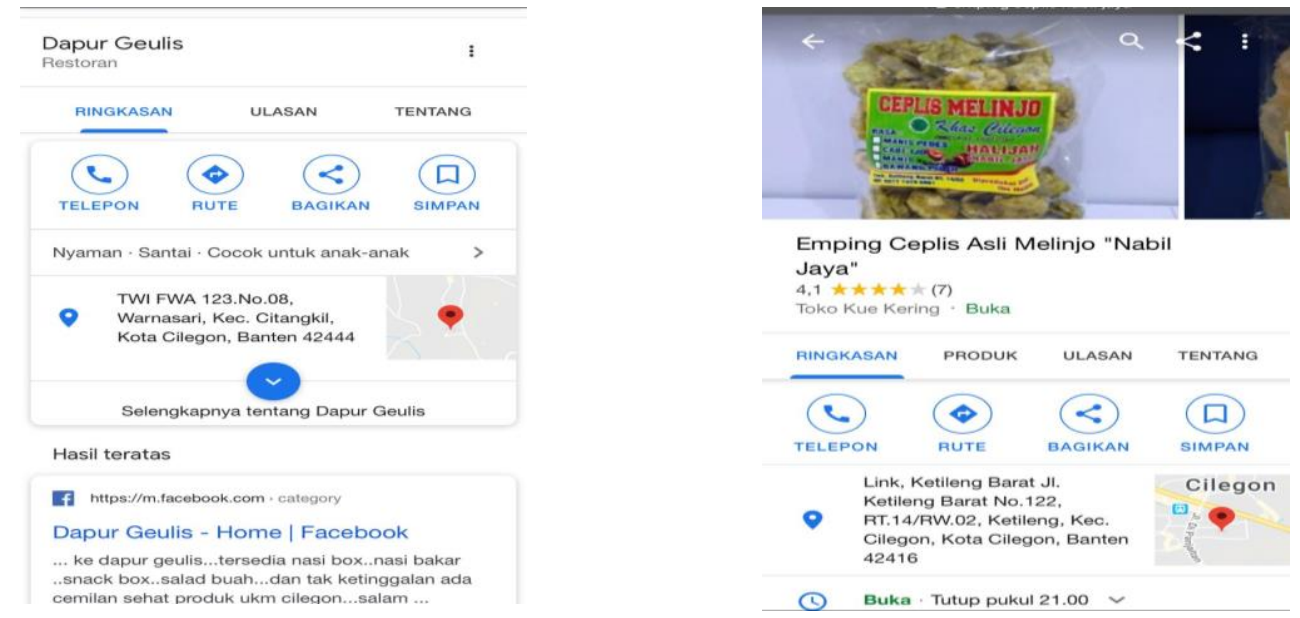

Gambar 5.

Hasil penerapan aplikasi google bisnisku untuk beberapa pelaku $\mathrm{UMKM}$

\section{SIMPULAN}

Kesimpulan dari pelaksanaan program pengabdian masyarakat dalam pengembangan jejaring bisnis produk lokal kota Cilegon

1. Dengan adanya kegiatan pengabdian kepada masyarakat mengenai pemberdayaan masyarakat dalam pengembangan jejaring bisnis produksi lokal kota Cilegon yang bertempat di Aula Gedung DPRD Cilegon memberikan manfaat mengenai strategi membangun jejaring bisnis secara online maupun offline terutama untuk produk lokal.

2. Dengan adanya pelatihan pengembangan jejaring binsis menggunakan google bisnisku, para mitra langsung mengaplikasikan penggunaan google bisnisku pada aktivitas pemasarannya. Sehingga pemasaran dan penjualan yang dulu dilakukan 
secara offline, setelah ada pelatihan dapat lebih optimal dengan mengintegrasikan secara secara online, sehingga penjualan semakin meningkat, karna jangkauan produk yang dipasarkan menjadi lebih luas.

3. Pelaku mitra UMKM dari berbagai jenis usaha yang tergabung dalam Pusat Inkubator Wirausaha dan Klinik UMKM (PIWKU) Kota Cilegon dan DISPERINDAGKOP Kota Cilegon mengharapkan ada kegiatan penyuluhan kembali terkait jejaring Bisnis.

Saran dari program kegiatan pengabdian pengembangan jejaring bisnis produk lokal kota Cilegon. Berdasarkan evaluasi yang dilakukan, kegiatan pengabdian ini perlu dilakukan secara rutin baik di lokasi yang sama atau lokasi yang berbeda dengan pelaku UMKM yang lebih banyak lagi, dengan sasaran pelaku UMKM yang benar-benar membutuhkan pengetahuan terutama tentang pengembangan jejaring bisnis. Selain itu perlu adanya pengembangan platform atau aplikasi yang dapat menampung produk-produk lokal agar para pelaku UMKM dapat memasarkan produknya lebih luas lagi.

\section{DAFTAR PUSTAKA}

Aliudin dan Dian Anggraeni. (2012). Nilai Tambah Emping Melinjo Melalui Teknologi Produksi Konvensional Di Desa Menes Kecamatan Menes Kabupaten Pandeglang. AGRIKA.

Ariani, A., \& Utomo, M. N. (2017). Kajian Strategi Pengembangan Usaha Mikro Kecil Ddan Menengah (UMKM) Di Kota Tarakan. Jurnal Organisasi Dan Manajemen. https://doi.org/10.33830/jom.v13i2.55.2017

BPS. (2018). Potensi Usaha Mikro Kecil Provinsi Banten. In BPS Provinsi Banten. https://banten.bps.go.id/publication/2018/12/31/2d3fd035d8b77447fd5e59f8/pote nsi-usaha-mikro-kecil-provinsi-banten-sensus-ekonomi-2016.html

BPS. (2019). Tingkat Pengangguran Terbuka (TPT) sebesar 5,01 persen. 2019-05-06.

Chang Shia, B., Chen, M., Ramdansyah, A. D., \& Wang, S. (2015). Comparison of Decision Making in Adopting E-Commerce between Indonesia and Chinese Taipei (Case Study in Jakarta and Taipei City). American Journal of Industrial and Business Management. https://doi.org/10.4236/ajibm.2015.512073

Dhyatmika, K. W. (2013). Analisis Ketimpangan Pembangunan Provinsi Banten Pasca Pemekaran. Diponegoro Journal Of Ecomonics.

Disperindag. (2018). Laporan Kinerja Intasnsi Pemerintah kota cilegon 2017 (Issue 2). http://disperin.cilegon.go.id/index.php/web/data/8/5

Rencana Strategis ( Renstra ) Kota Cilegon Periode Tahun 2016-2021, (2018). http://disperin.cilegon.go.id/index.php/web/data/8/5

Endaryono, B. T., \& Djuhartono, T. (2018). Membangun Jaringan Pasar untuk Mengembangkan Usaha Produk Lokal dalam Menumbuh Kembangkan Usaha Berbasis Sumber Daya Lokal melalui Usaha Mikro dan Keuangan Mikro. Sosio E-Kons. https://doi.org/10.30998/sosioekons.v10i3.2793

Paul M. Muchinsky. (2012). Google Bisnisku “ Gapura Digital.” In Google. https://doi.org/10.1017/CBO9781107415324.004

Janayu 1.2

Ramdansyah, A. D., \& Taufik, H. E. R. (2017). Adoption model of E-commerce from SMEs perspective in developing country evidence - Case study for Indonesia. In 
Jurnal Pengabdian dan Peningkatan Mutu Masyarakat, Vol. 1 No. 2, 168-177, 2020

Supriyanto, -. (2012). Pemberdayaan Usaha Mikro, Kecil dan Menengah (UMKM) Sebagai Salah Satu Upaya Penanggulangan Kemiskinan. Jurnal Ekonomi Dan Pendidikan. https://doi.org/10.21831/jep.v3i1.627

Janayu

1.2 